\title{
Perfiles
}

ROODY RÉSERVE

\section{Diógenes, "el Perro", solo contra todos}

La veracidad de los datos biográficos que se conservan sobre Diógenes aún es materia de discusión. Algunos autores dudan incluso que haya existido el personaje. Sin embargo, la historia de la filosofía está llena de anécdotas jocosas referentes a su persona. En éstas descansan, sin duda, las ideas que hoy nos hacemos de este singular individuo. Apodado "el Perro", debido a su estilo de vida estrafalario, el cínico asumió el mote sin complejo. Cuenta su biógrafo, su homónimo de Laercio, que cuando en un banquete unos comensales empezaron a tirarle huesos él se fue hacia ellos y les meó encima, como un perro.

En la Grecia antigua la palabra "perro" se usaba para referirse a las personas en que se destacaba de un modo peculiar el impudor franco de este animal. Había que atentar francamente contra el decoro y la decencia para hacerse acreedor de este calificativo. Por ejemplo, cuenta la tradición que una vez Zeus estaba tan enfadado con su esposa Hera que no encontró peor insulto para remarcar la desvergüenza con que ella había actuado, que decirle "no hay nada más perro que tú".

Consciente de la intención de insulto que animaba a quienes le apodaron el "Perro", Diógenes supo sacar provecho del calificativo. Llevó una vida de perro para llamar la atención de sus conciudadanos 
sobre la ruindad y la frivolidad de su sociedad. No temía ser vilipendiado, había ejercitado suficientemente hasta adquirir el don de la paciencia. Cuentan que solía pedir limosna a las estatuas y cuando le preguntaron por qué, contestó que así se acostumbraba a ser rechazado. Diógenes era consciente que para prosperar en su propósito tenía que nadar contra la corriente. Soportó del modo más digno, además con cierta alegría, esta obligación impuesta por la tozudez y necedad de sus compatriotas. De su actitud decía que se comportaba como el director de un coro que da la nota más alta para que todos los pupilos puedan captar el tono adecuado.

El mote de perro que asumió Diógenes supuso una ruptura con el modo de pensar griego de su época. En la tradición griega en que nació "el perro", los seres no gregarios por naturaleza no son tenidos en estima. Al respecto, Aristóteles comparó al hombre con las abejas para destacar que la única diferencia y, por consiguiente la marca de superioridad, reside en el uso del lenguaje en el primero. Porque tan sólo desde la palabra se puede expresar lo justo o injusto, lo conveniente o lo dañoso. Como se puede ver, el perro, a diferencia de las abejas, no es un "zoon politikón" o animal cívico. Se trata, más bien, de un animal insolidario con su especie, un compañero fiel del hombre en detrimento de su propia raza.

Sin embargo, hay una ventaja esencial en ser llamado perro y ser considerado como loco. Con eso se podía atacar, con cierta impunidad, la miopía atávica de la que sufría la sociedad de su tiempo. Diógenes tomó riesgos calculados cuando eligió este modo de vida sencillo y llamativo. Asumió conscientemente una actitud chocante para ser más coherente con su objetivo provocador y pedagógico. A la pregunta acerca de qué raza de perro era contestó: "cuando tengo hambre, un maltés; cuando estoy harto, un moloso, de esos que la mayoría elogia, pero que no se atreven a llevar con ellos de caza por temor a la fatiga. Así tampoco son ustedes capaces de convivir conmigo por temor a los dolores".

Provocar dolores a la sociedad hasta que fuera capaz de parir hombres nuevos fue el objetivo declarado de Diógenes. Para él, lo más importante era enseñar con el ejemplo. Por eso, entendió también que eso requería situarse por encima de la multitud. Dos anécdotas recuerdan de un modo peculiar este objetivo señalado. Por un lado, 
aborrecía de los que hablaban de lo correcto y no lo practicaban. Decía de éstos que no se diferencian en nada de una cítara que tampoco oye ni percibe. Por otro lado, cuando se enteró de que algunos se reían de sus extravagancias les dijo. "También de ustedes se ríen los asnos algunas veces; pero ni ustedes se cuidan de los asnos, ni yo de ustedes".

En definitiva, la simplicidad es palabra clave para definir el comportamiento chocante de Diógenes. Cuentan que una vez al observar a un niño que bebía en la cuenca de sus manos, arrojó de su zurrón su copa, diciendo: "un niño me ha aventajado en sencillez". De igual manera arrojó el plato al ver a un niño que, como le había roto el cuenco recogía sus lentejas en la corteza cóncava del pan. De igual modo, se rumora que él solía decir de su situación que quedó "sin ciudad, sin familia, privado de patria, pobre, vagabundo, tratando de subsistir día a día"

En la historia de la filosofía aparecen unas anécdotas biográficas que respaldan el programa ético que perseguía Diógenes. Nació en Sinope entre los años 413 y 400 a.C. Su padre era banquero y él mismo cuenta que un buen día, al consultar al oráculo de Delfos, éste le dijo que su misión consistía en troquelar la moneda en curso. Ante esta respuesta enigmática, Diógenes escogió a la vez los tres caminos posibles: falsificó la moneda, intentó modificar las leyes y se empeñó en transmutar los valores. Al percatarse las autoridades, le perdonaron la vida, pero lo condenaron al destierro. Situación que él recordaba con sarcasmo. A quien le echaba en cara que los sinopenses le habían condenado al destierro, él le replicó: "yo, a ellos, a la permanencia en su ciudad".

No hay que olvidar que en la sociedad griega de aquel tiempo el destierro era uno de los peores castigos al que un hombre podía ser condenado. Recuérdese que Sócrates decidió beber la cicuta antes de aceptar dejar su ciudad. Pues, Sócrates pensaba que su filosofía era para su ciudad, por lo tanto no tenía sentido fuera ella. Sólo en la ciudad se pueden realizar los hombres. Incluso Aristóteles, un advenedizo en Atenas, se suscribía a esta idea. Si bien que Diógenes adhirió a la idea de la realización humana dentro de la ciudad, dio a este concepto un sentido más amplio cuando habló de la ciudad como sinónimo de civilización. Asimismo, no olvidaba recalcar que sólo 
existe un gobierno justo: el del universo. Por ello, se puede concluir que si bien invitaba a aprovechar de los beneficios de la civilización, ésta en cambio no debería entrar en contracción con la ley natural suprema.

Diógenes, en cambio, se regocijaba de haber sido expulsado de su ciudad. Así, asumió sin titubeos el carácter "universal" de sus enseñanzas éticas y filosóficas. Por eso, cuando le preguntaron de dónde era contestó que de Cosmopolita. Con ello entra, sin duda, en la tradición sofista que empezó a cuestionar el carácter demasiado local de la filosofía griega, cuyos maestros reivindicaban, como hemos visto, la especificidad de su carácter y visión de mundo como forma de identidad y de realización humana por excelencia. Por ello, vio en su expulsión de Sinope una posibilidad para filosofar. Cuando alguien le volvió a recordar su condición de exilado le contestó "Pero por ese motivo, desgraciado, vine a filosofar".

Entonces, en el caso de Diógenes, antes que hablar de un cuerpo filosófico bien elaborado, conviene destacar la búsqueda de eficacia que anima al personaje. Así se podría decir que la filosofía de Diógenes tiene un propósito instructivo. Se trata de inculcar algunos valores fundamentales a los ciudadanos. Así entendido, el filósofo se constituye en la conciencia de su sociedad. A Hegesias, quien le pidió leer algunos de sus escritos, contestó: "iEres un frívolo Hegesias! Tú no echas mano a los higos pintados, sino a los de verdad. Pero en el ejercicio de la virtud dejas de lado lo real, y acudes a lo literario".

En la concepción filosófica de Diógenes, la virtud desempeña un papel preponderante. Se adquiere a través de la práctica constante y de la perseverancia en los propósitos. Creía que un doble entrenamiento espiritual y corporal era necesario para poner en el camino a quienes persiguen las acciones virtuosas. Consideraba al respecto que en la vida nada se puede conseguir sin entrenamiento y por medio de éste se puede mejorarlo todo. Por eso, quisieran vivir felices felices debieran de ejercitarse en la práctica de la virtud. El camino de la virtud se sigue ordenando las acciones personales de acuerdo a los mandatos de la naturaleza.

Diógenes asumió el objetivo de cuestionar los valores más anclados en su tiempo tales como el culto a los dioses y el respeto a los héroes. Asimismo, presenta una denuncia explícita en contra de la 
autoridad establecida. La anécdota en torno a la falsificación de la moneda es solamente una de las pruebas de esta actitud. También se cuenta que en una ocasión que se enteró que Alejandro había enviado una carta a Antípatro por medio de Atlio, el cínico declaró: "un miserable hijo de miserable a través de un miserable a otro miserable". De igual modo se portó, dicen, cuando tuvo en su presencia a Alejandro el grande. Éste le preguntó que le pidiera lo que quisiera, sólo le dijo que se hiciera a un lado porque le tapaba el sol.

Un argumento sencillo pero mordaz con el que el perro pone al descubierto la necesidad de evitar las derivas de una autoridad omnipotente. Diógenes no transige con su voluntad de cuestionar la autoridad de los príncipes. Con la misma medida llamó la atención sobre la hipocresía de la religión y de las farsas de los responsables de asuntos espirituales en Atenas. Cuentan que una vez al ver unos sacerdotes de un templo llevar preso a un sacristán que había robado un copón, exclamó: "Los grandes ladrones han apresado al pequeño". Al mismo tiempo, cuestionaba los privilegios que gozaban éstos en la sociedad. Por otra parte, ridiculizó la piedad ingenua de sus conciudadanos. Dijo respecto a los intérpretes de sueños, adivinos y sus adeptos, que ellos demuestran que no hay nada más vacío y tonto que el hombre.

Lo que buscaba en fin era proponer una nueva manera de vivir la tradición o los valores. Por eso, cuando le preguntaron qué es lo más hermosos entre los hombres, contestó que era la sinceridad. Él habló con sinceridad a sus congéneres y quiso que éstos fueran sinceros consigo mismos, con la tradición y con sus semejantes. En esto, Diógenes se sitúa en la línea de un predecesor ilustre. Al igual que Sócrates cree que tiene que enseñar con el ejemplo. La principal prueba de cercanía entre Diógenes y Sócrates la dio Platón que contestó que es un Sócrates enloquecido. $\mathrm{Al}$ igual que este insigne filósofo, el Perro creía en la urgencia de forjar hombres nuevos para rescatar la sociedad. Por eso decía que en Grecia no se ven hombres dignos en ninguna parte. Para que lo fueran, tendrían que aprender a ser honestos, vivir libres y buscar la felicidad.

Respecto del contenido del programa filosófico de Diógenes, la biografía elaborada por su homónimo no ofrece grandes pistas. Lo único que aparece claro es que hay un rechazo a todas las concepciones filosóficas en vigor. Ridiculizó las enseñanzas de Crátero, 
Anaxímenes y Platón, que consideraba como pérdidas de tiempo. Cuando este último dio su definición de hombre como animal bípedo implume, el Perro desplumó un gallo y lo presentó ante todos como el hombre de Platón. En cambio, aprendió a filosofar en compañía de Antístenes, el fundador de los cínicos, de quien dicen que convenció gracias a su perseverancia, no obstante el rechazo de éste que no admitía alumno.

Sin embargo, en el fondo, se observa una cierta vaguedad con respecto a los planteamientos de Diógenes. Sin duda, esa vaguedad condena a la ineficacia y desdén el objetivo primordial de éste. Al igual que los ascetas que se aislaban para denunciar la locura de su mundo, Diógenes intentó llamar la atención sobre las incongruencias de su sociedad. Su insolencia destacó el carácter libre del filósofo. Y decía al respecto que la filosofía le había salvado de no ser cualquier cosa y de haberle permitido estar bien equipado contra cualquier azar. Pero también estaba consciente que la filosofía está hecha para conducir a los hombres. Por eso dicen que cuando lo querían vender como esclavo y el pregonero le preguntó por lo que sabía hacer él contestó que gobernar hombres. Para él, los sabios no sólo tenían el derecho de gobernar a los demás, sino también se trataba de una exigencia divina. Por eso decía: si todo es propiedad de los dioses, los sabios son amigos de los dioses y la propiedad de los amigos son comunes. Por lo tanto, todo debía pertenecer a los sabios.

En fin, el canto de Diógenes es a la libertad. Libertad de espíritu y libertad ante las leyes y ante las convenciones de su tiempo. Por eso su estilo de vida buscaba asemejarse lo más posible a la naturaleza. Sólo siguiendo los mandatos de la naturaleza se puede erigir una sociedad de virtud y no de vicios. Cuentan que al observar a un ratón que corría sin preocuparse de un sitio para dormir y sin cuidarse de las comodidades convencionales, encontró Diógenes una solución para adaptarse a sus circunstancias y simplificar su vida. Se consiguió un morral para llevar sus provisiones. Dormía, dialogaba y comía en la calle como un vagabundo.

La educación puede llevar a los hombres a esta libertad soñada. El entrenamiento espiritual y corporal es el medio privilegiado para conseguir estos objetivos. Diógenes dio prueba, con su vida, de que no hay que desfallecer en este trabajo. Dicen que murió de cólico, a los 
noventa años, después de haber comido un pulpo vivo, siempre en su línea de imitar la naturaleza. Diógenes no pensaba descansar por la vejez porque consideraba consejos similares como un insulto inadmisible. Se preguntaba, ¿si corriera la carrera de fondo, debería descansar al acercarme al final, o más bien apretar más? Así dedicó su vida a la educación de sus semejantes recalcando que ésta era "sensatez para los jóvenes, consuelo para los viejos, riqueza para los pobres y adorno para los ricos".

\section{Bibliografía:}

Diógenes Laercio, La secta del perro, Vidas de los filósofos cínicos, Alianza Editorial, Madrid, 1990. Traducción de García Carlos Gual. 